\title{
DEMOKRACJA BEZPOŚREDNIA VERSUS INTEGRACJA MNIEJSZOŚCI MUZUtMAŃSKIEJ W SZWAJCARII
}

\section{Mirosław Matyja*}

Abstrakt

Przedmiotem tego artykułu jest analiza roli mniejszości muzułmańskiej w Szwajcarii. Szwajcarski system polityczny demokracji bezpośredniej blokuje prawa muzułmańskiej mniejszości religijnej i jej pełną integrację w społeczeństwie. Ograniczenie pełnych praw mniejszości potwierdza zjawisko dysfunkcyjności w tym systemie demokracji bezpośredniej.

Słowa kluczowe: Szwajcaria, szwajcarski system polityczny, demokracja bezpośrednia, mniejszość muzułmańska, federalizm, inicjatywa ludowa „stop minaretom”, referendum

\section{DIRECT DEMOCRACY VERSUS \\ INTEGRATION OF THE MUSLIM MINORITY IN SWITZERLAND}

\begin{abstract}
The analysis of the role of the Muslim minority in Switzerland is the subject of this article. The Swiss political system is blocking the rights of Muslim religious minority and its full inte-gration in Switzerland and in the Swiss society. In Switzerland, the negative impact of direct democracy on the integration of Muslim religious minority exists. Limitation of full rights for the minority confirms the phenomenon of dysfunctionality in the Swiss direct democracy system.
\end{abstract}

Keywords: Switzerland, Swiss political system, direct democracy, Muslim minority, federalism, popular initiative "stop minaret", referendum

\footnotetext{
*Prof. Mirosław Matyja, Polski Uniwersytet na Obczyźnie, Londyn, e-mail: miroslaw.matyja@puno.edu.pl | ORCID: https://orcid.org/0000-0001-6776-9410
} 
Wstęp

Szwajcarska demokracja bezpośrednia utrudnia i wręcz blokuje przeprowadzenie równouprawnienia mniejszości muzułmańskiej w tym kraju. J ednak nie tylko formy demokracji bezpośredniej, referendum i inicjatywa ludowa, wpływają negatywnie na integrację ugrupowań muzułmańskich. Dużą rolę odgrywają w tym procesie również elity polityczne, które co prawda akceptują i uznają prawa mniejszości muzulmańskiej, to jednak nie przedstawiają ich postulatów na forum parlamentu - w obawie przed walką polityczną w wypadku ewentualnego referendum.

W niniejszym artykule podjąłem próbę zweryfikowania hipotezy: demokracja bezpośrednia w Szwajcarii wpływa hamująco i blokująco na proces integracji mniejszości muzułmańskiej w tym kraju. Koronnym przykładem tego zjawiska jest przedstawione w artykule referendum federalne dotyczące zakazu budowy muzułmańskich minaretów w roku 2009, które wywołało w Szwajcarii publiczną debatę na temat wpływu systemu politycznego tego kraju na równouprawnienie religijne muzułmańskiej mniejszości.

Zastosowanie w artykule znalazła metoda instytucjonalno-prawna i związana z nią - z uwagi na specyfikę tematu - analiza aktów normatywnych, przede wszystkim rangi konstytucyjnej i ustawowej.

Demokracja bezpośrednia jest podstawą system politycznego w Szwajcarii jest elementem i funkcjonuje w obowiązującym systemie politycznym tego państwa. Stąd analiza systemowa umożliwiła dokonanieinterpretacji rzeczywistości politycznej w tym systemie politycznym.

Natomiast zgodnie z modelem racjonalnego wyboru, decyzje podejmowane w ramach instytucji demokracji bezpośredniej powinny być oceniane przez pryzmat kalkulacji korzyści i kosztów, jakie ze sobą niosą. Obywatel, podejmujący decyzję w referendum czy zgłaszający 
projekt ustawy w ramach inicjatywy ludowej, kieruje się zasadą maksymalizacji użyteczności. W praktyce okazuje się, że racjonalność jednostkowa nie zawsze jest zbieżna $\mathrm{z}$ racjonalnością zbiorową, ocenianą zwłaszcza z perspektywy długofalowej. Analiza empiryczna wybranego referendum („stop minaretom”) i jego konsekwencji pozwoliła na ocenę tych rozbieżności w przypadku integracji mniejszości muzułmańskiej w systemie szwajcarskiej demokracji bezpośredniej.

Formy demokracji bezpośredniej

System federalny oraz idea udziału obywateli w procesie podejmowania decyzji politycznych w formie demokracji bezpośredniej stanowią istotną część historii Szwajcarii (Nitszke 2013; Aleksandrowicz 2009). Wśród form demokracji bezpośredniej w tym państwie wyróżniamy głównie: zgromadzenieludowe, inicjatywę ludową oraz referendum obligatoryjne i fakultatywne (Marczewska-Rytko 2012).

Tabela 1. Formy demokracji bezpośredniej w Szwajcarii

\begin{tabular}{lll}
\hline Federacja & Kantony & Gminy \\
\hline referendum obligatoryjne & referendum obligatoryjne & referendum obligatoryjne \\
\hline referendum fakultatywne & referendum fakultatywne & referendum fakultatywne \\
\hline inicjatywa ludowa & inicjatywa ludowa & inicjatywa ludowa \\
\hline kontrprojekt & zgromadzenie ludowe & inicjatywa indywidualna \\
\hline & & zgromadzenie lokalne \\
\hline
\end{tabular}

Źródło: Musiał-Karg 2012, S. 154. 
Podstawowymi i najczęściej stosowanymi formami demokracji bezpośredniej są inicjatywa ludowa oraz referendum, które są realizowane zarówno na szczeblach lokalnych (tj. w kantonach i gminach), jak i federalnym (por. tabela 1).

Kolektywny system władzy oraz duży wpływ grup interesów i obywateli w Szwajcarii nie znajdują odpowiednika wżadnym innym państwie. Nawet jeśli w innych krajach istnieją systemy zbliżone do demokracji bezpośredniej, to jednak nie da się ich porównać z systemem szwajcarskim z powodu jego specyfiki i rozbudowanej formy oddolnego podejmowania decyzji (Kost 2008).

$\mathrm{W}$ tym miejscu powstaje trudne zadanie zdefiniowania sprawnie funkcjonującego systemu demokratycznego i jego instrumentów polegających na subsydiarności (Meyer 2009). Stosowanie form demokracji bezpośredniej obejmuje wszystkie szczeble administracji publicznej, od władzy lokalnej poczynając, na federalnej kończąc. Formy te służą spolecznej kontroli władzy przedstawicielskiej, ale muszą liczyć się z nią także rządzący i elity polityczne. Pod głosowanie są poddawane różne problemy, o mniejszym i większym znaczeniu dla państwa. Wynika to z dużej swobody politycznej Szwajcarów, dzięki której każda sprawa polityczna może stać się przedmiotem inicjatywy ludowej. W takiej sytuacji rządzący nie obawiają się podnoszenia kwestii trudnych, które mogłyby okazać się barierą dla reelekcji - dlatego nie zachowują się konformistycznie (Kużelewska 2011, s. 317).

Referendum to podstawowa, kształtowana przez stulecia, forma demokracji bezpośredniej umożliwiająca obywatelom decydowanie o sprawach publicznych (Musiał-Karg 2008; Kużelewska 2006). Największe zastosowanie znajduje na szczeblu gminy, a mniejsze - na szczeblu kantonu oraz federacji. Referendum stanowi wiążącą dla władz wypowiedź społeczną, rodzącą skutki prawne w dziedzinie, której dotyCzy (Branecki 2011, s. 175). 
W Szwajcarii funkcjonują dwie postaci tej formy demokracji bezpośredniej: referendum obligatoryjne oraz referendum fakultatywne (Degen 2011, ss. 166-168).

Zgodnie zart. 140 konstytucji, przedmiotem referendum obligatoryjnego są trzy grupy zagadnień:

- zmiana Konstytucji Federalnej;

- akcesja do organizacji zbiorowego bezpieczeństwa lub do wspólnot ponadnarodowych;

- ustawy federalne uznane za pilne, które nie mają podstaw konstytucyjnych i których czas obowiązywania jest dłuższy niż jeden rok (wówczas w ciągu roku od przyjęcia takiej ustawy przez Zgromadzenie Federalne musi ona być przedłożona pod głosowanie).

Referendum obligatoryjne zostało wprowadzone w życie już w roku 1848, stosuje się je w razie konieczności wprowadzenia zmian do konstytucji. Natomiast od roku 1977 referendum to zwołuje się także w sprawie decyzji o przystąpieniu do organizacji ponadnarodowych. W art. 140 pkt 2 konstytucji zawarto postanowienia dotyczące zastosowania referendum obligatoryjnego:

„Narodowi przedstawia się pod głosowanie:

a) inicjatywy ludowe w sprawie całkowitej zmiany Konstytucji Federalnej;

b) inicjatywy ludowe w sprawie częściowej zmiany Konstytucji Federalnej w formie propozycji o ogólnym charakterze, która została odrzucona przez Zgromadzenie Federalne;

c) pytanie, czy należy przeprowadzić całkowitą zmianę Konstytucji Federalnej w razie niejednomyślności obu izb" (Konstytucja Federalna Konfederacji Szwajcarskiej 2000).

Referendum fakultatywne wprowadzono wroku 1874. Zwołujesięje dla wyrażenia sprzeciwu wobec rozwiązań przyjętych w obowiązującym systemie prawa. Instytucja ta jest stosowana przeciwko uchwalonemu 
aktowi prawnemu. Zgodnie z art. 141 konstytucji, zajego przeprowadzeniem musi opowiedzieć się 50 tys. osób lub co najmniej osiem kantonów. Wymagana liczba podpisów pod wnioskiem o takie referendum musi być zebrana w okresie 100 dni od ogłoszenia (publikacji) w Dzienniku Federalnym (Bundesblatt) tekstu aktu prawnego będącego przedmiotem głosowania (Braun 2008, s. 28).

Według art. 142 konstytucji, projekty przedstawione pod głosowanie narodowi stają się obowiązujące utedy, gdy opowie się za nimi większość głosujących (Hug 2004, ss. 321-336).

Nastepną formą jest inicjatywa ludowa, o której mowa wart. 138, 139 i 139b ustawy zasadniczej z roku 1999. Ta forma odgrywa istotną rolę w tym modelu demokracji bezpośredniej (Aleksandrowicz 2013). J ej przedmiotem może być całkowita lub częściowa rewizja Konstytucji Federalnej. Całkowita zmiana ustawy zasadniczej może być zaproponowana przez 100 tys. obywateli uprawnionych do głosowania, którzy w ciągu 18 miesięcy zbiorą wymagane podpisy (Marczewska-Rytko 2012, s. 273).

Najogólniej mówiąc, inicjatywa ludowa polega na tym, że grupa 100 tys. obywateli uprawnionych do głosowania może wystąpić z żądaniem wprowadzenia poprawek konstytucyjnych, zaproponować nowe rozwiązania prawne oraz uchylić funkcjonujące.

Inicjatywa może dotyczyć zarówno rozwiązań szczegółowych, jak i tych natury ogólnej. J eśli taka propozycja się pojawi, tojest poddawana pod dyskusję na forum Rady Federalnej oraz Zgromadzenia Federalnego, które ustosunkowują się formalnie do proponowanych rozwiązań, czyli zgłaszają inne propozycje lub uszczegółowiają te przedstawione. Następnie wszystkie inicjatywy, łącznie z kontrpropozycjami, są poddawane pod osąd społeczeństwa i poszczególnych kantonów w referendum. Inicjatywa ludowa uzyskuje akceptację wtedy, gdy opowie się za jej przyjęciem większość społeczeństwa i większość kantonów. 
W szwajcarskim systemie politycznym wyróżnia się inicjatywę ludową mającą na celu przyjęcie nowej konstytucji oraz inicjatywę mającą na celu wniesienie poprawek konstytucyjnych. Pierwszy rodzaj inicjatywy istnieje od roku 1848, drugi zaś - od 1891.

W kantonach realizujących głosowanie przez zgromadzenie ogółu obywateli przedmiotem inicjatywy ludowej może być w zasadzie każdy projekt. Z wnioskiem o podjęcie proponowanego rozwiązania może wystąpić każdy obywatel, który jest członkiem zgromadzenia. W kantonach, gdzie funkcjonują przedstawicielskie organy uchwałodawcze, prawo wnoszenia inicjatywy ludowej przysługuje tylko określonej liczebnie grupie obywateli, a dotyczyć możejedynie spraw zastrzeżonych do kompetencji głosowania powszechnego (wybór władz, budżet, ważniejsze wydatki obsada personalna urzędów) (Banaszak 2007, ss. 248-249).

Zgromadzenie Ludowe jest swoistym zebraniem uprawnionych obywateli, którzy gromadzą się na wolnym powietrzu na centralnym placu kantonu (Landsgemeindeplatz), aby debatować i decydować o najważniejszych kantonalnych kwestiach (Grabowska 2009, s. 158). Przedmiotem każdego zgromadzenia ludowego są sprawy istotne dla mieszkańców. Podczas tych corocznych spotkań decyduje się m.in. o prawie czy o wydatkach kantonalnych. Każdy uczestnik ma możliwość zabrania głosu w debacie. Głosowanie odbywa się przez podniesienie ręki i każdorazowo traktowane jest jako referendum o charakterze obligatoryjnym. J ak podaje Bogusław Banaszak (2007, s. 301)., istnieje możliwość przeprowadzenia głosowania tajnego lub ograniczenia przedmiotu zgromadzenia ludowego tylko do wyboru określonych organów bądź głosowania nad jakąś sprawą bez uprzedniej dyskusji. Z powodów praktycznych Landsgemeinde zostało zniesione we wszystkich kantonach z wyjątkiem dwóch - Glarus i Appenzell Innerhoden, gdzie nadal jest najwyższą instytucją polityczną na szczeblu kantonalnym.

W około 80\% gmin funkcjonują także tzw. zgromadzenia obywateli (zgromadzenielokalne) - Gemeindeversammlung (znane też pod nazwą 
Einwohnerversammlung). Spotykają się wówczas wszyscy zainteresowani uprawnieni do głosowania, aby podejmować decyzje w kwestiach najważniejszych dla swoich wspólnot lokalnych. Zgromadzenia wgminach są w istocie kopią kantonalnych Landsgemeinde, w przeciwieństwie do nich jednak organizowane są kilka razy w roku (Helg 2007, s. 17).

W skład zgromadzenia gminy wchodzą wszyscy uprawnieni do głosowania. Zależnie od przyjętego w kantonie systemu organizacji zgromadzenie ma moc uchwałodawczą lub jest zwoływane w celu ustanowienia organu przedstawicielskiego mającego moc uchwałodawczą (Matyja 2009). Do kompetencji zgromadzenia należą m.in. uchwalanie budżetu gminy i zatwierdzanie jego wykonania, istotnymi zadaniami są uchwalanie podatków, wybór władz gminnych i nadzór nad ich działalnością oraz przyjmowanie sprawozdań z działalności organów gminnych.

\section{Muzułmanie w Szwajcarii}

Muzułmańska społeczność w Szwajcarii jest pod względem wielkości trzecią grupą religijną w tym kraju. Ponad 5\% społeczeństwa szwajcarskiego przynależy do tej religijnej wspólnoty (Bundesamt für Statistik Sektion Demografie und Migration b.r.).

Współżycie chrześcijan i muzułmanów wymaga ustawicznego rozwiązywania trudnych integracyjnych problemów, które rodzą się niejako automatycznie w wypadku zetknięcia się różnych religii i kultur, jakimi są chrześcijaństwo i islam (Tanner 2008). Okazuje się to nie zawsze latwe, nawet w kraju liberalnym i demokratycznym, jakim jest Szwajcaria. Zasadniczą kwestią jest przyznanie praw, a jeśli tak - to w jakim wymiarze - współobywatelom będącym wyznawcami religii niechrześcijańskich. Tzw. podstawowe prawa przysługują bowiem wszystkim mieszkańcom alpejskiej republiki (Kälin 2000).

Napływ społeczności muzułmańskiej do Szwajcarii związany jest bezpośrednio z migracją ekonomiczną i polityczną uchodzców z tzw. 
krajów trzeciego świata i państw byłej J ugosławii z jednej strony oraz ostatnią falą uchodzców z Afryki Północnej i z Azji z drugiej. Muzułmanie żyjący w obrębie Konfederacji Szwajcarskiej zrzeszeni są w ok. 160 stowarzyszeniach, które troszczą się o budowę meczetów, ośrodków kulturalnych i szkół Koranu. Dwie trzecie muzułmanów to sunnici, znaczącą grupę tworzą także szyici i alewici. Stowarzyszenia muzułmańskie na terenie Szwajcarii są bardzo zróżnicowane politycznie i nieufne wobec siebie oraz reprezentują różne odłamy islamu. Dlatego też nie potrafią wyłonić jednego przedstawiciela, który byłby reprezentatywny i prowadził dialog z władzami szwajcarskimi.

Z prawnego punktu widzenia egzystowanie muzułmanów w Szwajcarii nastręcza wiele wyzwań, bowiem systemy prawne tych „dwóch światów” różnią się zasadniczo: prawo muzułmańskie opiera się na woli boskiej, natomiast Konfederacja Szwajcarska to demokratyczne państwo prawa i jako takie opiera się na woli społeczeństwa. Rodzi się tu problem stosunku muzułmanów do świeckiego państwa i jego demokratycznej tożsamości. Islam nie jest bowiem oficjalnie uznaną religią w republice szwajcarskiej ${ }^{1}$.

Wymienione niejasności, jak i wiele innych aspektów, generują w Szwajcarii konieczność międzykulturowego dialogu między państwem i ugrupowaniami muzułmańskimi, który stanowiłby podstawę wspólnej płaszczyzny porozumiewania się. Są to problemy nieposiadające oczywistych rozwiązań, wymagające rozmów, których stan w chwili obecnej można określić jako niezadowalający, zarówno na szczeblu Konfederacji, jak i kantonalnym. Powodem tego jest wspomniany brak reprezentatywnej muzułmańskiej instytucji oraz nierozwiązana kwestia prawna statusu tej społeczności. Dla Szwajcarii jest to stosunkowo nowa sytuacja społeczno-polityczna, dodatkowo utrudniona ze względu na zdecentralizowany federalizm i system demokracji bezpośredniej, który bynajmniej nie ułatwiajednolitej integracji społeczności muzułmańskiej.

' Oficjalnie uznane religie w Szwajcarii to: katolicyzm, protestantyzm, judaizm. 
Wolność sumienia i wyznania, a więc wolność przynależności do danej religii, jest zagwarantowana wart. 15 konstytucji szwajcarskiej, w którym państwo jest zobowiązane zagwarantować obywatelom ich religijną i wyznaniową neutralność. Należy jednak zwrócić uwagę na fakt, że według konstytucji, państwo gwarantuje ochronę i neutralność religijną, jednak - w przeciwieństwie do polityki wobec mniejszości językowych - nie przejmuje aktywnej roli w odniesieniu do mniejszości religijnych.

Inicjatywa „Stop minaretom"

Sytuacja konfliktowa, dotycząca uznania mniejszości religijnych, związana jest w Szwajcarii wyłącznie z uznaniem tych praw dla mniejszości muzułmańskiej, co poniekąd odzwierciedla albo powiela sytuację w innych krajach zachodnioeuropejskich (Roy 2002). Kampania inicjatywy dotyczącej zakazu budowy minaretów - już symboliczna w swych wymiarach politycznych i społecznych - zapoczątkowana została w roku 2007 przez polityków prawicowych ze Szwajcarskiej Partii Ludowej (SVP). Następnie została ona dość niespodziewanie pozytywnie przyjęta przez elektorat szwajcarski (57,5\%) w referendum 29 listopada 2009 roku. Przegłosowany na szczeblu federacji zakaz budowy muzułmańskich minaretów miał swój początek w wydarzeniach w miejscowości Wangen w kantonie Solura, gdzie wniosek o budowę minaretu został złożony w roku 2005. Protesty przeciwko tej budowie napływały z wielu środowisk, również ze strony obydwu kosciołów chrześcijańskich w państwie szwajcarskim. Najczęstszymi argumentami przeciwników była obawa przed rozprzestrzenianiem się fundamentalizmu, zagrożenie stabilności religijnej i zmiana krajobrazu miejscowości Wangen. Co ciekawe, budowa ta nie kolidowała z prawem budowlanym w Szwajcarii i w kantonie Solura (Die bau- und planungsrechtliche Gleichbehandlung im Lichte der Glaubens- und Gewissensfreiheit: Gutachten für 
die Eidgenössische Ausländerkommission 2004). SVP argumentowała, że minarety nie są obiektami o charakterze religijnym, a jedynie „wyraźnymi symbolami polityczno-religijnych roszczeń do władzy”. Szwajcarskiej Partii Ludowej udało się w stosunkowo krótkim czasie zebrać wymagane sto tysięcy podpisów i wnieść sprawę pod ogólnonarodowe referendum.

Kampania przedrefendalna

Znamienne były reakcje opinii publicznej w okresie debaty poświęconej zakazowi budowy wież świątyń sakralnych dla wyznawców islamu, podczas której dominowały negatywne stereotypy, jak np. pojawienie się dominacji muzułmańskich fundamentalistów, „islamizacja regionu”, zagrożenie dla szwajcarskiej świadomości narodowej itd.

Inicjatorzy kampanii „stop minaretom”2 argumentowali konieczność wprowadzenia państwowego zakazu budowy świątyń muzułmańskich przede wszystkim aspektami politycznymi (Matyja 2014, s. 107i nast.). Według nich, minaret jest religijno-politycznym symbolem islamu i demonstruje potęgę tej konfesji. Praktyki religijne nie stoją tu na pierwszym miejscu, minaret jest głównie widziany jako polityczna oznaka siły mniejszości muzułmańskiej w Szwajcarii (El-Sonbati 2010). Obawiali się oni równiė̇, że pozwolenie na budowę będzie początkiem ustępstw wobec mniejszości muzułmańskiej w Szwajcarii.

Zasadniczą motywacją przedstawianą przez zwolenników inicjatywy zakazu była teza, że wyrażenie zgody na budowę minaretów w Szwajcarii będzie jednocześnie zagrożeniem dla wartości narodowych i jawnym przyzwoleniem na rozwój niedemokratycznych tendencji. Pojawiał się także argument, że minarety nie są elementami koniecznymi dla meczetów, a zakaz ich budowy nie zagraża wolności religijnej muzułmanów (Kley, Schaer 2009, s. 87 i nast).

\footnotetext{
${ }^{2}$ Niem. Bau von Minaretten ist verboten.
} 
Zwolennicy nieblokowania budowy minaretów, będący jednocześnie przeciwnikami inicjatywy, wyznawali pogląd, że minarety są tak samo ważne dla wyznawców islamu, jak wieże kościelne dla wyznawców religii chrześcijańskich. Pierwsze minarety powstały na świeciebowiem już 1500 lat temu, 60 lat po śmierci proroka Mahometa, i od tamtego czasu stanowią nieodłączną część tradycji religijnej. Rozpoczęcie budowy minaretów przy meczetach winno być symbolem uznania religii muzulmańskiej w Szwajcarii i niejako wyjściem islamu z cienia dominujących religii chrześcijańskich ${ }^{3}$. Dzięki temu muzułmanie mogliby się poczuć bardziej zasymilowani i zaakceptowani przez spoleczeństwo alpejskiego kraju. Oprócz tego minaret dla muzułmanów jest świadectwem ich tożsamości religijnej i nie zagraża innym religiom.

Przeciwnicy inicjatywy zarzucili inicjatorom zakazu budowy minaretów populizm w przededniu wyborów parlamentarnych, które odbyły się 21 października 2007 roku. Ich głównymi argumentami byly: swoboda wyznania w Szwajcarii, wewnętrzny pokój państwa i ich obawa o wizerunek liberalnego i neutralnego kraju za granicą.

W czasie kampanii przedreferendalnej dużo kontrowersji wywołał plakat komitetu inicjatywy „Przeciwko budowie minaretów”, przedstawiający muzułmankę z zakrytą twarzą, stojącą przed leżącym szwajcarskim krzyżem, na którym stoją liczneminarety. Plakat został ostro skrytykowany, gdyż minarety miały formę rakiet. W niektórych miastach i kantonach zabroniono umieszczania plakatu w miejscach publicznych. Szwajcarska Rada Federalna i obydwie izby parlamentu odrzucily w głosowaniu inicjatywę „stop minaretom” i polecily przeglosowanie tej inicjatywy na „nie”" (Bundesrat gegen Bauverbott für Minarette 2008). Rada Federalna podkreśliła na oficjalnej konferencji prasowej 15 października 2009 roku, że inicjatywa narusza zasady wolności wiary i wyznania, równouprawnienie obywateli oraz zagraża stabilności religijnej w państwie. Dla rządu i parlamentu od początku inicjatywa stała

3 W Szwajcarii do roku 2009 istniało około 160 meczetów i miejsc modlitw dla muzułmanów bez minaretów. 
w sprzeczności z wartościami wolnego społeczeństwa i demokracji. J ednocześnie rząd szwajcarski przeprowadził kampanię poza granicami kraju, aby osłabić tam pojawienie się negatywnych reakcji ośrodków politycznych, szczególnie wśród przedstawicieli świata muzułmańskiego.

Referendum „Stop minaretom”

Olbrzymia większość społeczeństwa szwajcarskiego głosowała 29listopada 2009 roku pozytywnie, sprzeciwiając się budowie minaretów na terytorium Szwajcarii. Zaledwie wczterech kantonach (Bazylea-Miasto, Genewa, Neuenburg i Waadt) inicjatywę „stop minaretom” odrzucono, głosując na „nie”. Rada Kantonów w parlamencie szwajcarskim zagłosowała zatem:

Tak (19 1/2 kantonu)

Nie (3 $1 / 2$ kantonu)

Gminy wiejskie zdecydowanie odrzuciły możliwość budowy minaretów na terytorium państwa szwajcarskiego (65,9\% na „tak”), podobnie uprawnieni do głosowania w gminach miejskich (54,2\% na „tak”), choć tu odsetek głosów był niższy niż wynosiła średnia krajowa (57,5\% na „tak”). Negatywne nastawienie do postulatu budowy minaretów było najwyższe w Szwajcarii włoskojęzycznej (68,2\% na „tak”), podczas gdy część francuskojęzyczna była bardziej liberalna (48,3\% na „tak”).

Dla większości głosujących, którzy opowiedzieli się za zakazem budowy minaretów oddanie pozytywnego głosu dla inicjatywy miało być wyrazem sprzeciwu wobec minaretów jako symbolowi islamizacji Szwajcarii i Europy Zachodniej. Argumentowano przy tym, że uchwalenie zakazu nie wiązało się z naruszeniem podstaw gwarantowanej wolności religijnej dla muzułmanów ani możliwością uprawiania przez nich praktyk religijnych (Schaer 2009a, s. 1). Szwajcarzy postrzegali swoją decyzjęjako obronę wartości chrześcijańskich i odwet za dyskryminację chrześcijan w niektórych krajach islamu. Stosunkowo często podnoszonym argumentem były przyczyny estetyczne: co piąty głosujący uważał, że 
minarety nie pasują do rodzimego krajobrazu, zdominowanego przez symbole chrześcijańskie (Hüttermann 2006). Natomiast stosunkowo rzadkim argumentem był protest przeciwko osiadłym na stałe muzułmanom.

Dla przeciwników inicjatywy najważniejszym argumentem było naruszenie swobody wyznania i religii oraz dyskryminacyjny charakter inicjatywy (Vatter, Milic, Hirter 2011, s. 160). Co szósty głosujący twierdził, że w inicjatywie nie chodzi o zakaz budowy minaretów, a cała kampania ma charakter konfrontacji politycznej. Istniejące już na terenie Szwajcarii cztery minarety nie doprowadziły bowiem wcześniej do konfliktu na tle religijnym (Stüssi 2009, s. 596). Przeciwnicy inicjatywy podawali także jako przyczynę głosowania na „nie” nietolerancję społeczeństwa oraz chęć prawicy do wywołania konfliktu religijnego z ugrupowaniami muzułmańskimi. Spora grupa była również zdania, żeminarety nieprzeszkadzają im w codziennym życiu (Vatter, Milic, Hirter 2011, s. 160), a zakaz budowy wież sakralnych w Szwajcarii stoi w sprzeczności z zakazem dyskryminacji i wrezultacie generuje wiele negatywnych skutków prawnych, jak np. osłabienie polityki przestrzegania praw człowieka, prowadzoną aktywnie przez neutralne państwo, szczególnie wobecpaństwislamskich. Oprócz tego osłabia koncepcję państwa demokracji bezpośredniej, której utrzymanie wedle niektórych opinii stanęło pod znakiem zapytania. Decyzja Szwajcarów z 29 listopada 2009 roku pokazała bowiem, że system demokracji bezpośredniej nie jest w stanie dostatecznie chronić mniejszości religijnych i wchodzi w sprzeczność z prawami podstawowymi (Stüssi 2008). Argumentowano, że elity polityczne mogą manipulować opinią publiczną i sterować decyzjami elektoratu w kierunku realizacji własnych, partykularnych interesów.

Kwestie prawne

Wynik referendum wykazał fakt wpływu polityki poza granicami państwa na politykę wewnętrzną Szwajcarii. Negatywny obraz islamu przeniknął 
bowiem do alpejskiego kraju z zagranicy, szczególnie po 11 września 2001 roku i po serii ataków terrorystycznych, które ze Szwajcarią nie miały nic wspólnego. Zrodziła się islamofobia, która pozwoliła prawicowym elitom politycznym wytworzyć „obraz wroga”, jakim miałby być właśnie islam i jego wyznawcy.

Według opinii ekspertów prawa międzynarodowego, w neutralnym światopoglądowo i demokratycznym państwie zostały naruszone podstawy tradycyjnej zasady praworządności. Ta zasada, zwana równiė̇ „państwem prawa w sensie formalnym”, została zapisana wart. 5 pkt 1 konstytucji szwajcarskiej: „Podstawę i granicę działalności państwowej stanowi prawo”. Przyczyny przegłosowania inicjatywy na „tak” były różnorodne, jednak jedna z nich zdecydowanie dominowała. W różnych badaniach opinii publicznej potwierdza się, że głosujący za inicjatywą chcieli wyrazić tym swój protest przeciw rozszerzaniu się w Szwajcarii wpływu islamu i przeciw modelowi społeczeństwa propagowanemu przez tę religię. Dla chrześcijan był to niemal automatyczny odruch protestu przeciwko obcej religii, bez uprzedzeń do jej założeń, lecz tylko ze względu na odmienność. Dużą rolę odegrała również postawa elit opiniotwórczych i politycznych, wywołana reakcją na wzrost fali terroryzmu. Ukazywanie islamu przez wiele lat w świetle zagrożenia wpłynęło na przekonania głosujących. Na uwagę zasługuje również to, że 40\% badanych deklarujących się jako zwolennicy Szwajcarii otwartej na zewnątrz i równych szans dla Szwajcarów i obcokrajowców głosowało za przyjęciem inicjatywy (a więc za zakazem budowy minaretów).

Natychmiast po przegłosowaniu inicjatywy w Szwajcarii rozpoczęła się debata na temat naruszenia zasad konstytucyjnych (Schaer 2009b, s. 5), podstawowych praw człowieka i obywatela oraz relacji między zmianą art. 72 konstytucji (wprowadzenie zakazu budowy minaretów) a prawem międzynarodowym. Sugerowano nawet, aby unieważnić wyniki referendum (Stüssi 2008). J est bowiem regułą, że w wypadku czę- 
ściowych zmian konstytucji szwajcarskiej, które są następstwem inicjatywy ludowej, nie może dojść do konfliktu z prawem międzynarodowym. Potwierdza to art. 193 pkt 4 konstytucji: „Nie mogą zostać przy tym naruszone obowiązujące postanowienia prawa międzynarodowego” oraz art. 194 pkt 2 konstytucji: „Zmiana częściowa musi zachować jedność materii i nie może naruszać obowiązujących postanowień prawa międzynarodowego". Podobnie rewizja konstytucji, co jest niezmiernie ważne z prawnego punktu widzenia, nie może kolidować z międzynarodowym prawem humanitarnym. Według art. 139 pkt 3 konstytucji: „J eżeli inicjatywa narusza jedność formy, jedność materii lub bezwzględnie obowiązujące postanowienia prawa międzynarodowego, Zgromadzenie Federalne uznaje ją za całkowicie lub częściowo nieważną".

Inicjatywa i referendum „stop minaretom” wydaje się kolidować przede wszystkim z Europejską Konwencją Praw Człowieka, której Szwajcaria jest sygnatariuszem. Dlatego już przed głosowaniem 29 listopada 2009 roku dyskutowano nad ewentualnym unieważnieniem omawianej inicjatywy. Przeciwnicy zakazu budowy minaretów argumentowali swoje racje ryzykiem ograniczenia wolności religijnej i wyznaniowej wSzwajcarii i złamaniem zasady zawartej wart. 9 ust. 1 wyżej wymienionej Konwencji, wktórym jest mowa o prawie do wykonywania praktyk religijnych z uwzględnieniem specyficznych zwyczajów i obyczajów. Artykuł 9 ust. 2 konwencji umożliwiajednak uchwalenie ustawy o ograniczeniu wolności religijnej w spoleczeństwie demokratycznym w wypadku ochrony prawi wolności innych religii. Zwolennicy inicjatywy twierdzili natomiast, że wolność religii i wyznania nie została naruszona, nie zabroniono bowiem budowy meczetów, które są właściwymi świątyniami dla wyznawców islamu, leczjedynie minaretów.

Przyjęcie inicjatywy przez społeczeństwo szwajcarskie wywołało mieszane uczucia nie tylko w Szwajcarii, lecz także na świecie. Rozpę- 
tała się debata medialna na temat możliwości budowy minaretów i stosunku państw demokratycznych do muzułmańskich mniejszości. Oburzenie wywołało przeciwstawienie się Szwajcarii zasadom prawa międzynarodowego, które propagują i chronią wolność religii i wyznania (Matyja 2015, s. 59 i nast). Rada Europy zażądała od Szwajcarii zniesienia zakazu budowy minaretów tak szybko, jak to tylko możliwe. Zakaz uznano za „dyskryminujący” i na okres przejściowy Rada Europy zaleciła Szwajcarii wprowadzenie moratorium na jego stosowanie. Rezolucję w tej sprawie uchwaliło jednomyślnie Zgromadzenie Parlamentarne Rady Europy w Strasburgu. Podkreślono, że zakaz „dyskryminuje społeczność muzułmańską i narusza Europejską Konwencję PrawCzłowieka”. Pomijając kwestie prawne, decyzja społeczeństwa szwajcarskiego była jednak takżeoceniana dodatnio, jako odważne opowiedzenie się przeciwko wpływom islamu w Europiei w obronie wartości chrześcijańskich.

Osobna debata toczyła się na temat wpływu instrumentów demokracji bezpośredniej na przyznanie równych praw wszystkim członkom społeczeństwa bez względu na wiarę, przynależność religijną i światopogląd. Zrodziły się pytania, czy istnieją rozsądne granice demokracji bezpośredniej i czy tego rodzaju demokracja nie jest swego rodzaju „mieczem Damoklesa”, zagrażającym rozwojowi społeczno-instytucjonalnemu państwa szwajcarskiego.

\section{Podsumowanie}

Analiza inicjatywy i referendum w sprawie zakazu budowy minaretów wskazuje na fakt, że współkształtowane przez część elity politycznej argumenty dotarły do społeczeństwa i wpłynęły decydująco na nastawienie głosujących. Za zakazem budowy wież na świątyniach muzułmańskich głosowały osoby, które zostały przekonane przez argumenty o kulturowym zagrożeniu stwarzanym przez islam dla świata zachodniego. Natomiast obywatele, którzy uważali, iż argumenty politycznej 
prawicy są przesadzone i nieadekwantne do domniemanego zagrożenia ze strony islamu, głosowali na „nie”. W konsekwencji wyborcy nie opowiadali się w istocie za prawem muzułmanów do budowy minaretów (czy prawem do swobody praktyk religijnych jako takich), lecz wyrażali swój punkt widzenia na temat polityczno-kulturowego konfliktu, przejawiącego się w obawach o utratę zachodnich wartości pluralistycznospołecznych. Nastawienie głosujących było zdominowane przez mocno zarysowany podział między lewicą i prawicą. W tej sytuacji to umiarkowane partie polityczne „środka” były w stanie okreslić i określiły ostateczny wynik referendum, przede wszystkim Chrześcijańsko-Demokratyczna Partia Ludowa Szwajcarii (Matyja 2016, ss. 130-137).

Inicjatywa „stop minaretom” była najistotniejszym referendum dotyczącym praw muzułmanów w Szwajcarii, wskazującym na ogromny wpływ narzędzi demokracji bezpośredniej na przebieg konfliktów związanych z zakresem praw mniejszosci niechrześcijańskich w państwie. Wynik głosowania wydaje się potwierdzać opinie z innych źródel mówiące, że prawa muzułmanów w Szwajcarii są zawężone (lub ich przyznanie tej mniejszości znacznie spowolnione) przez istniejące prawodawstwo, w porównaniu z oficjalnie uznanymi wyznaniami. Instytucje państwowe czują się odpowiedzialne za przyznanie mniejszościom podstawowych praw religijnych, natomiast dla społeczeństwa aspekty prawne odgrywają zaledwie rolę drugoplanową. Społeczności lokalne przyjmują perspektywę gminy czy kantonu, nie przykładając większej wagi do abstrakcyjnie pojmowanej wolności religijnej i wyznaniowej (Vatter, Danaci 2010: 205-222). Właśnie na tym poziomie Szwajcarska Partia Ludowa mobilizowała społeczeństwo do opowiedzenia się przeciwko budowie muzułmańskich wież sakralnych.

Należy przy tym dodać, że sam zakaz minaretów był dla prawicy drugorzędny. Politykom prawicowym chodziło w większym stopniu o zainscenizowanie protestu przeciwko konkretnej, tj. muzułmańskiej mniejszości religijnej i wskazanie na potencjalne zagrożenie ze strony islamu dla 
kultury szwajcarskiej. Referendum stanowiło dogodną sposobność do zmobilizowania społeczeństwa po stronie prawicy przed zblizającymi sie wyborami do parlamentu.

W ostatnich latach, mimo iż daje się zaobserwować praktyczny zanik sytuacji konfliktowych między obiema podstawowymi religiami chrześcijańskimi Szwajcarii - katolikami i protestantami - na porządku dziennym występuje konflikt związany ze społeczno-prawną akceptacją mniejszości muzułmańskiej (Mashood, 2003). Dla państwa szwajcarskiego jest to stosunkowo nowa sytuacja. Musi się ono określić wobec obaw o utratę podstawowych historycznych, cywilizacyjnych i „tożsamościowych" wartości, a także wobec istniejącego poczucia zagrożenia (Baghdadi, 2009). Można się spodziewać, żew następnych debatach dotyczących praw mniejszości muzułmańskiej (np. w kwestii okrycia twarzy kobiet w miejscach publicznych) tendencje pozostaną te same. Nie chodzi tu bowiem tylko o konflikt prawny w wąskim tego słowa znaczeniu, lecz o etniczno-kulturowy podział w społeczeństwie (Vatter, Danaci 2010, s. 210 i nast.). Ów podział przebiega między zwolennikami wartości tradycyjnych i narodowych zjednej strony i protagonistami otwartej i zglobalizowanej Szwajcarii z drugiej (Lienmann 2007).

Należy stwierdzić, że w praktyce szwajcarski system polityczny, w którym dominują elementy demokracji bezpośredniej, wpływa ograniczająco na równouprawnienie mniejszości religijnych, w szczególności muzułmanów. Ponadto, decyzje podjęte w drodze zastosowania instytucji demokracji bezpośredniej doprowadziły pośrednio do konfliktu z prawem międzynarodowym (Pahud de Mortanges, 2002).

Szwajcaria, jak cała współczesna Europa, stoi dziś przed koniecznością odpowiedzi na strategiczne wyzwania o cywilizacyjnym charakterze. J ednym z kluczowych problemów jest przyszły kształt tego wielokulturowego społeczeństwa z jego całą mozaiką różnych mniejszości i grup narodowych (Die viersprachige Schweiz 2000). 
Szwajcaria, w przeciwieństwie do większości współczesnych społeczeństw europejskich, nigdy nie stanowiła społeczeństwa jednorodnego etnicznie; zamiast tego wewnętrzną spoistość kreowały i wzmacniały jednolita tożsamość, historia i kultura. Obecnie jednak, na skutek pojawienia się mniejszości muzułmańskiej, doszło do wzrostu napięć spolecznych i zmiany preferencji wyborczych, co przejawiło się w konsekwencji we wzroście poparcia dla ugrupowań skrajnej prawicy.

Deklarowany powszechnie w Szwajcarii pozytywny stosunek do procesów integracyjnych, budowany na bazie wielowiekowej szwajcarskiej tradycji tolerancji dla „innych”, traci wyraźnie na sile w konfrontacji z koniecznością ustosunkowania się do nowych, nieznanych dotąd kwestii szczegółowych (Christmann 2011, s. 207i nast).

J akie zatem działania i zmiany ze szwajcarskiej perspektywy są niezbędne, aby zachodzący aktualnie proces opornej i powolnej integracji mniejszości muzułmańskiej przebiegał harmonijnie, bez zbędnych napięć i konfliktów? Wydaje się, że kluczem do powodzenia są zmiany świadomości społecznej, zwłaszcza zaś niezbędne jest odejście od absolutyzowania dwóch istotnych mitów.

Po pierwsze, zerwanie z ortodoksyjnie pojmowanym prymatem religii chrześcijańskich. J est faktem bezspornym, że podstawy kultury europejskiej w tradycyjnym rozumieniu tworzą: chrześcijaństwo, dorobek greckiej i rzymskiej cywilizacji, spuścizna europejskiego oświecenia oraz wynikający z tych tradycji indywidualizm. J ednak wyzwania, jakie stoją przed Szwajcarią, wymagają uznania praw obywateli-niechrześcijan do wspólistnienia na równych prawach z chrześcijańską większością.

Po drugie, konieczna wydaje sie rewizja koncepcji narodu. Współczesne, a zwłaszcza przyszłe życie publiczne Szwajcarii (i Europy) wymaga istotnej modyfikacji tradycyjnej koncepcji narodu i daleko idących redefinicji związanych z nią kategorii, jakimi są demokracja - państwo narodowe - społeczeństwo obywatelskie (Kunze 2005). 
Kluczowa będzie aktywność i świadomość obywatelska, i to, czy i w jakim stopniu obywatele będą skłonni uwzględniać problematykę narodową i ponadnarodową w relacji do specyfiki lokalnej. Wynik tej debaty będzie interesujący i ważny dla całego zachodniego kręgu cywilizacyjnego.

Bibliografia

Aleksandrowicz M. (2003), Miejsce inicjatywy ludowej w konsensualizmie szwajcarskim [w:] Wspótczesna demokracja bezpośrednia: dialog polsko-szwajcarski, (red.) Wiśniewska-Paź B., Aureus, Kraków Aleksandrowicz M. (2009), System prawny Szwajcarii: historia i wspótczesność, Temida 2, Białystok

Baderin Mashood A. (2003), International Human Rights and Islamic Law, Oxford University Press, Oxford

Banaszak B. (2007), Porównawcze prawo konstytucyjne wspótczesnych państw demokratycznych, Wolters Kluwer, Warszawa

Branecki T. (2011), Szwajcarskie referendum „Stop minaretom” - podstawa prawna, wyniki i skutki, „Atheneum” nr 32

Braun N. (2008), Direct Democracy in Switzerland. Case Study [w:] Direct Democracy. The International IDEA Handbook, International Institute for Democracy and Electoral Assistance (International IDEA), Stockholm

Bundesrat gegen Bauverbott für Minarette (2008), Komunikat prasowy Rady Federalnej, 27.08

Bundesamt für Statistik Sektion Demografie und Migration (b.r.), Religionen, https://www.bfs.admin.ch/bfs/de/home/ statistiken/bevoelkerung/ sprachen-religionen/ religionen.html [16.05.2018] 
Christmann A. (2011), Die Grenzen direkter Demokratie. Volksentscheide im Spannungsverhältnis von Demokratie und Rechtsstaat, Nomos, Baden-Baden

Degen B. (2011), Referendum [w:] Historisches Lexikon der Schweiz, Bd. 10: Pro-Schafroth, Schwalbe, Basel

Die viersprachige Schweiz (2000), (Hrsg.) Bickel H., Schläpfer R., Sauerla nder Verlag, Aarau- Frankfurt am Main- Salzburg

El-Sonbati J . (2010), Moscheen ohne Minarett. Eine Muslimin in der Schweiz, Zytglogge, Oberhofen am Thunersee

Grabowska S. (2009), Formy demokracji bezpośredniej w wybranych państwach europejskich, Wyd. Uniwersytetu Rzeszowskiego, Rzeszów Helg F. (2007), Die schweizerischen Landsgemeinden. Ihre staatsrechtliche Ausgestaltung in den Kantonen Appennzell Ausserrhoden, Appenzell Innerrhoden, Glarus, Nidwalden und Obwalden, Schulthess juristische Medien AG, Zürich- Basel- Genf

Hug S. (2004), Occurrence and Policy Consequences of Referendums: A Theoretical Model and Empirical Evidence, "J ournal of Theoretical Politics" No. 16 (3)

Hüttermann J . (2006), Das Minarett. Zur politischen Kultur des Konflikts um islamische Symbole, Beltz J uventa, Weinheim

Kälin W. (2000), Grundrechte im Kulturkonflikt: Freiheit und Gleichheit in der Einwanderungsgesellschaft, NZZ Libro, Zürich

Die bau- und planungsrechtliche Gleichbehandlung im Lichte der Glaubens- und Gewissensfreiheit: Gutachten für die Eidgenössische Ausländerkommission (2004), (Eds.) Kiener R., Kuhn M., Eidgenössische Ausländerkommission, Bern

Kley A., Schaer A. (2009), Gewährleistet die Religionsfreiheit einen Anspruch auf Minarett und Gebetsruf? [w:] Streit um das Minarett. Zusammenleben in der religiös pluralistischen Gesellschaft, (Hrsg.) Tanner et al. M., Zytglogge, Zürich 
Konstytucja Federalna Konfederacji Szwajcarskiej (2000), Wydawnictwo Sejmowe, Warszawa, http://libr.sejm.gov.pl/tek01/txt/ konst/ szwajcaria.html

Kost A. (2008), Direkte Demokratie, Springer VS, Wiesbaden

Kunze R.-U. (2005), Nation und Nationalismus, Wissenschaftliche Buchgesellschaft, Darmstadt

Kużelewska E. (2006), Referendum $w$ procesie integracji europejskiej, oficyna Wydawnicza ASPRA, Warszawa

Kużelewska E. (2011), Udział Szwajcarskiego Zgromadzenia Federalnego $w$ postępowaniach referendalnych [w:] Parlamentaryzm $w$ świecie współczesnym. Miedzy idea a rzeczywistością, (red.) Mołdawa T., Zaleśny J ., Dom Wydawniczy Elipsa, Warszawa

Lienmann W. (2007), Kippa, Kruzifix, Kopftuch - Kulturkampf? Der Rechtsstaat als Herausforderung und Chance heutiger Religionen, [w:] Religionsfreiheit. Schweizerische Perspektiven, (Hrsg.) Bernhardt R., Kuhn T.H., Theologischer Verlag Ag, Zürich

Marczewska-Rytko M. (2012), Inicjatywa ludowa i referendum w Szwajcarï w latach 200o-2010, „Polityka i Społeczeństwo” nr 9

Matyja M. (2009), System polityczny Szwajcarii. Federalizm i demokracja bezpośrednia, „Kultura i Historia” t. 16

Matyja M. (2014), Granice demokracji. Wpływ szwajcarskiego systemu demokracji bezpośredniej na proces integracyjny muzulmańskiej mniejszości religïnej, Poligraf, Brzezia Łąka

Matyja M. (2015), Dysfunkcjonalność szwajcarskiego systemu demokracji bezpośredniej na przykładzie procesu integracji mniejszości muzutmańskiej, „Studia Politicae Universitatis Silesiensis” t. 14

Matyja M. (2016), Dysfunkcjonalność szwajcarskiej demokracji bezpośredniej, Adam Marszałek, Toruń

Meyer T. (2009), Was ist Demokratie? Eine diskursive Einführung, Springer VS, Wiesbaden 
Musiał-Karg M. (2008), Referendum w państwach europejskich. Teoria, praktyka, perspektywy, Adam Marszałek, Toruń

Musiał-Karg M. (2012), Elektroniczne referendum w Szwajcarï. Wybrane kierunki zmian helweckiej demokra-cji bezpośredniej, Wyd. WNPiD UAM, Poznań

Nitszke A. (2013), Zasady ustroju federalnego w państwach niemieckojęzycznych. Studium porównawcze, Krakowska Oficyna Wydawnicza, Kraków

Pahud de Mortanges R. (2002), Muslime und Schweizerische Rechtsordnung - Les musulmans et l'ordre juridique Suisse, Academic Press Freiburg, Freiburg

Roy O. (2002), L'Islam mondialisé, Seuil, Paris

Schaer A. (2009a), Minarettinitiative: Im Widerspruch zur Verfassung, "Akzente" No. 17 (2)

Schaer A. (2009b), Probleme lösen, nicht schaffen, "EVP-Info des Kantons Aargau" No. 4

Stüssi M. (2008), Muss das Parlament die Minarettverbotsinitiative für ungültig erklären?, Univercity of Lucerne, Luzern

Stüssi M. (2009), Schweizer Minarettverbot. Ein Einzelfall?, "Schweizerische Kirchenzeitung" No. 36

Tanner E. (2008), Die muslimische Minderheit und ihre Religion. Strukturrchtliche und institutionsrechtliche Grundfragen im Bereich des Religionsrechts der Schweizerischen Eidgenossenschaft, Lit Verlag, Fribourg

Vatter A., Danaci D. (2010), Mehrheitstyrannei durch Volksentscheide? Zum Spannungsverhältnis zwischen direkter Demokratie und Minderheitenschutz, "Politische Vierteljahresschrift" 51 (2)

Vatter A., Milic T, Hirter H. (2011), Das Stimmverhalten bei der NZZ Libro, Zürich 